\title{
Pengaruh Sikap pada Ebook dan Sikap pada Buku Fisik terhadap Minat Baca Masyarakat di Era Industri 4.0
}

\author{
Dewi Nurbaiti ${ }^{1}$, Mariah $^{2}$ \\ 1,2 Kalbis Institute \\ dewi.nurbaiti@kalbis.ac.id
}

\section{ARTICLE INFO}

\section{Article History}

Received : 30 December 2019

Reviewed: 5 Pebruary 2020

Published: 30 April 2020

Available Online: 30 April 2020

Keywords:

book, ebook, publisher

industry, digital

\begin{abstract}
One of the creative industry' products which are inside of it are writings and pictures produced from one's creative thinking is book. For some communities, reading physical books are still an option if compared with reading digital book or called e-book. This is related with the age, neighborhood, social status and the level of education. Along with the development of the times, there has been a lot of growing up the publishing industry and also the profession of book writer, but it is not end by printing physical books, but in digital platform only. The process of e-book selling is increase every day and it become a capable industry to sustain the economic needs of communities. The quantitative research that compiled by collecting questionnaire data to the people of Jakarta and surrounding areas provides data presentation that Ebooks and physical books are important factors that influence people's interest in reading in the industrial era 4.0. Both types of books have their own appeal to attract individual mints according to different age groups.
\end{abstract}

\section{A. PENDAHULUAN}

Menurunnya kinerja penjualan buku fisik di Indonesia mulai jelas terlihat sejak tahun 2015. Pola masyarakat dalam membeli dan membaca yang mulai bergeser, membuat industri penjualan buku fisik turut terkena imbasnya. Beberapa toko buku telah menutup gerainya anatara lain Aksara, sebuah toko buku yang menjual buku-buku impor dan kini telah meninggalkan pesaingnya yakni Books and Beyond. Untuk menyeimbangkan pemasukan dari penjulan buku fisik, pemilik toko buku melengkapi bisnisnya dengan membuka gerai online untuk melayani pembelian melaui internet. Selain itu yang juga dilakukan oleh Books and Beyond selaku toko buku Lippo Group, dengan membuat jaringan penjualan online untuk buku digital. Dengan bergesernya budaya membaca masyarakat Indonesia saat ini tentu saja perlu dilakukan berbagai penyesuaian tersebutagar dapat bertahan atau minimal dengan adanya pendapatan dari jaringan online dapat mensubsidi pendapatan yang menurun dari penjualan secara langsung di toko buku yang semakin menurun. Strategi ini juga dilakukan oleh toko buku besar di Indonesia yaitu Gramedia, dengan menyediakan jaringan toko buku online untuk memfasilitasi para pelanggannya dalam membeli buku dengan cara yang lebih simpel, dipilih oleh Gramedia sebagai salah satu cara untuk mempertahankan bisnisnya saat ini. Semakin menurunnya grafik penjualan dalam dunia perbukuan tidak hanya dialami oleh industri penjualan buku fisik saja, tetapi juga oleh usaha penerbitan dan percetakan. Berada dalam mata rantai bisnis yang sama dalam hal penjualan buku fisik, industri penerbitan dan percetakan buku pun mengalami penurunan grafik yang signifikan, sebagai akibat dari ancaman kemajuan teknologi saat ini.

Menulis untuk diterbitkan dalam versi buku digital juga menjadi pertimbangan tersendiri bagi para penulis maupun calon penulis buku. Hal ini disebabkan karena menulis buku dalam bentuk elektronik dan dalam bentuk fisik memiliki perbedaan yang dapat memberikan keuntungan lebih bagi penulisnya. Salah satunya adalah dalam hal gaya Bahasa tulisan, dalam sajian buku fisik penulis diharuskan mengikuti kaidahkaidah yang berlaku termasuk EYD yang baik dan benar. Akan tetapi dalam buku versi digital penulis dapat menulis dengan gaya bahasanya sendiri. Hal ini yang turut menyumbang turunnya minat menulis buku fisik, selain karena proses kreatif tersebut dalam hal royalti penjulan untuk buku fisik lebih banyak dikuasai oleh penerbit, serta dalam hal penulisan yang lebih kaku dan harus tetap berada dalam koridor yang baik dan benar. Seiring dengan berkembangnya zaman di mana saat ini telah memasuki era revolusi industri 4.0, internet of things memang menjadi dasar bagi hampir setiap aktifitas manusia. Salah satu yang mengalami 
peralihan teknologi akibat adanya perubahan era tersebut adalah buku. Sebelum memasuki era revolusi industri 4.0, buku berupa kumpulan tulisan yang dicetak di atas kertas lalu dijilid atau dijadikan satu menjadi sebuah buku. Dalam hal penggunaan buku fisik seseorang harus membawa beberapa buku untuk dapat membaca beberapa topik bahasan yang berbeda-beda. Buku fisik juga memiliki keterbatasan lain terkait bahan dasar pembuatannya yaitu kertas. Dalam ukuran waktu tertentu kertas akan menjadi usang dan lama kelamaan akan rusak. Bahkan tidak membutuhkan waktu yang lama, jika terkena air saja seketika buku akan rusak dan sulit untuk dibaca. Berbeda dengan ebook atau buku digital, buku yang dibaca melalui gawai lebih awet selama gawai itu sendiri tidak terkena virus. Di dalam sebuah gawai juga dapat disimpan ratusan atau bahkan ribuan judul buku untuk dapat dibaca kapan saja. Cukup membawa satu gawai saja maka beraneka macam buku dapat dibaca dengan mudah. Buku digital juga dianggap lebih ramah lingkungan karena tidak menggunakan kertas yang berasal dari kayu pepohonan sebagai bahan dasarnya.

Industri buku juga mengalami peralihan teknologi. Setelah menjadi buku digital tentu ada individu yang memilih membaca buku digital atau tetap setia pada buku fisik. Masing-masing memiliki alasan, yang bisa jadi alasannya tersebut memengaruhi minatnya dalam membaca. Semakin sepinya penjualan buku fisik bukan tidak mungkin menurunkan minat baca masyarakat yang enggan beralih ke ebook, namun telah sulit menemukan buku fisik yang menjadi pilihannya. Namun sebaliknya bisa saja minat baca masyarakat justru meningkat dengan adanya ebook yang menjanjikan kemudahan dan kepraktisan seseorang saat membacanya.

\section{Tujuan Penelitian}

Berikut ini adalah tujuan dari penelitian :

1. Untuk mengetahui pengaruh sikap pada ebook terhadap minat baca masyarakat DKI Jakarta.

2. Untuk mengetahui pengaruh sikap pada buku fisik terhadap minat baca masyarakat DKI Jakarta.

3. Untuk mengetahui pengaruh sikap pada ebook dan sikap pada buku fisik terhadap minat baca masyarakat DKI Jakarta secara bersama-sama.

\section{Model Konseptual Penelitian}

Melalui penelitian ini dapat dilihat ada atau tidaknya pengaruh sikap pada ebook dan sikap pada buku fisik terhadap minat baca masyarkat DKI Jakarta, di mana ebook dan buku fisik merupakan variabel bebas dan minat baca merupakan variabel terikat. Dengan demikian penelitian ini merupakan penelitian asosiatif. Penelitian asosiatifadalah penelitian yang memiliki tujuan untuk mengetahui hubungan antara dua variabel atau lebih. Penelitian ini akan membangunsebuah teori yang berfungsi untuk menjelaskan, meramalkan dan mengontrol suatu gejala (Sugiyono, 2012: 36).Kerangka pemikiran dari masalah yang ada digambarkan dalam model penelitian sebagai berikut:

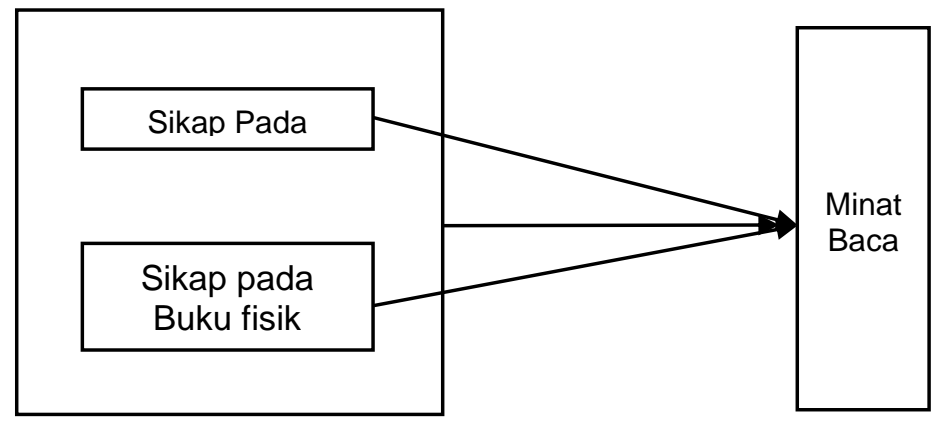

Gambar 1 Model Konseptual Penelitian

\section{B. METODOLOGI}

Sikap pada buku fisik dimaksudkan sebagai faktor yang menentukan perilaku seperti apa yang akan akan dilakukan oleh individu terhadap buku fisik. Sikap ini akan mengarahkan perilaku kepada munculnya rasa ketertarikan atau minat terhadap buku fisik dan akhirnya menimbulkan sikap memutuskan untuk membaca buku fisik. Perilaku ini yang menjadi kunci apakah seseorang akan menaruh minat atau tidak serta apakah seseorang akan membaca buku fisik atau tidak. Ekspresi mengenai suka atau tidak sukanya seseorang terhadap sesuatu hal dipengaruhi oleh faktor psikologi dari dalam diri manusia. Selain faktor psikologi terdapat juga faktor lainnya yaitu sosiologi yang berarti latar belakang budaya manusia, serta hakekat manusia sebagai mahluk sosial. Faktor sosiologi ini akan mempengaruhi seseorang untuk mengambil 
keputusan, sebagian besar faktor sosiologi ini memegang peranan penting di mana kondisi kelompok atau lingkungan terdekat seseorang akan memberikan pengaruh yang kuat dalam pengambilan keputusan.

Era digital seperti saat ini menjadi faktor yang berpengaruh pada individu dalam hal penentukan sikap pada ebook. Budaya masyarakat yang serba digital dapat menjadi perilaku yang akan mempengaruhi individu lainnya untuk menyukai ebook. Selain faktor yang datang dari dalam diri seseorang, ada juga faktor dari luar diri yang sama-sama memiliki pengaruh besar pada keputusan seseorang untuk menyukai ebook atau tidak. Seikap pada ebook dimaksudkan sebagai perilaku dan dorongan psikologis dari dalam diri manusia sebagai proses tertentu dalam menumbuhkan minat pada ebook dan menyukai ebook atau sebaliknya. Perilaku di era industry 4.0 ini memberikan dorongan yang kuat pada individu untuk bersikap menyukai ebook. Hal ini didorong pula oleh kondisi industri buku fisik yang mulai menurun dan digantikan dengan buku digital.

Minat baca dimakisudkan sebagai perilaku yang datang dari dalam diri individu untuk memiliki ketertarikan pada aktivitas membaca. Minat baca datang sebagai perilaku konsumen yang kuat dipengaruhi oleh faktor psikologis maupun sosiologi, yang telah melalui proses dari dalam diri manusia hingga pada akhirnya tumbuh minat atau ketertarikan untuk melakukan sesuatu, dalam hal ini minat untuk membaca. Minat baca adalah proses sebelum terjadinya keputusan untuk membaca atau kemudian membaca ulang, dalam teori minat beli dikatakan sebagai minat untuk membeli dan minat beli ulang. Minat baca dalam diri individu dapat mengarah pada dua jenis buku dalam penelitian ini yaitu buku fisik atau buku digital atau yang dalam penelitian ini disebut dengan ebook.Pendidikan menjadi faktor penting yang melandasi seseorang untuk berbuat dan bersikap. Demikian pula terhadap pemanfaatan teknologi informasi maupun segala hal yang berbasis internet, apakah dimanfaatkan untuk kemudahan aktifitas sehari-hari atau sebaliknya, tidak diambil banyak manfaatnya dengan alasan tertentu. Di mana seseorang tinggal, berada di lingkungan seperti apa juga akan menentukan sikap dari individu tersebut dalam berbuat dan bersikap. Pengaruh yang datang dari lingkungan tempat tinggal cukup mampu membuat seseorang memutuskan sesuatu. Demikian pula terhadap kemajuan teknologi yang saat ini begitu cepat, seseorang yang tinggal di lingkungan A tentu akan berbeda tanggapannya dengan seseorang yang tinggal di lingkungan B.

\section{Populasi dan Sampel}

Suharsimi Arikunto (2013) menjelaskan bahwa populasi merupakan keseluruhan subjek dari penelitian. Selain itu definisi lain mengenai populasi oleh Sugiyono (2000) yaitu wilayah generalisasi yang terdiri atas : obyek/subyek yang mempunyai kualitas dan karakteristik tertentu yang ditetapkan oleh peneliti untuk dipelajari dan kemudian ditarik kesimpulannya. Target populasi dari penelitian ini adalah penduduk DKI Jakarta.

Sampel merupakan bagian dari populasi yang diharapkan oleh peneliti dapat merepresentasikan keseluruhan populasi. Sampel adalah sebagian untuk diambil dari keseluruhan objek yang diteliti dan dianggap mewakili seluruh populasi (Soekidjo, 2005). Peneliti mengelompokkan sampel pada usia, pendidikan terakhir, pekerjaan, jumlah pengeluaran, profesi dan lokasi tempat tinggal, untuk masyarakat DKI Jakarta yang berusia di atas 20 tahun, sehingga termasuk dalam kategori jugdemental sampling karena peneliti menganggap sampel tersebut dapat mewakili populasi yang ingin diteliti.Menurut Suharsimi Arikunto (2013) sampel adalah sebagian atau wakil populasi yang diteliti. Definisi sampel menurut Sugiyono (2000) sampel adalah bagian dari jumlah dan karakteristik yang dimiliki oleh populasi tersebut. Penelitian ini dimaksudkan untuk melakukan analisa terhadap pengaruh hubungan antar variabel, atau sering disebut juga dengan analisis regresi. Dalam analisis regresi, variabel yang mempengaruhi disebut variabel bebas (Independent Variable), sedangkan variabel yang dipengaruhi disebut variabel terikat (Dependent Variable). Sampel dalam penelitian ini mengacu pada teori Gay dan Diehl (1992)dimana dalam sebuah penelitian jumlah sampel minimum dapat sejumlah adalah 30 subjek. Dalam penelitian ini peneliti menggunakan metode pengambilan sampelyang mengacu pada teknik probability sampling jenis area sampling, dimana populasi dikelompokkan berdasarkan letak geografisnya, namun setiap anggota populasi memiliki kesempatan yang sama untuk dijadikan sampel.

\section{Metode Pengumpulan Data}

Penelitian ini menggunakan metode pengumpulan data melalui survei kuesioner. Pengambilan data survei dilakukan dengan memberikan pertanyaan personal melalui kuesioner digital dan juga secara langsung kepada responden. Kuesioner dalam penelitian ini akan disajikan menjadi beberapa bagian yaitu: 


\section{a. Introduction}

Adalah tahap untuk mengenal secara singkat tentang identitas diri peneliti, tujuan dari penelitian dan permintaan mengenai kesediaan responden untuk mengisi kuesioner.

\section{b. Data Demografi}

Adalah bagian yang menyajikan pertanyaan-pertanyaan terkait dengan identitas responden berupa usia, pekerjaan, pendidikan terakhir,jumlah pengeluaran, pekerjaan dan lokasi tempat tinggal.

c. Pertanyaan Inti

Pada tahap ini peneliti memberikan pertanyaan yang langsung berkaitan dengan variabel penelitian, yang nantinya dilakukan analisa datanya oleh peneliti.

Penelitian ini menggunakan duajenis format pertanyaan :

1. Close-ended Question dan open-ended question, jenis pertanyaan ini akan memberikan pilihan jawaban yang dapat dipilih oleh responden. Jenis pertanyaan ini digunakan pada pertanyaan yang berkaitan dengan data demografi responden.

2. Scaled response question, jenis pertanyaan ini akan menggunakan skala dalam mengukur atribut penelitian. Dalam penelitian ini akan menggunakan skala likert dimana skala ini akan mengukur persepsi maupun perilaku dari responden terhadap variabel penelitian ini.

\section{Metode dan Analisis Data}

Metode dan analisis data yang digunakan pada penelitian ini adalah uji validitas, uji reliabilitas, uji normalitas, uji heterokedastisitas, uji multikolinearitas, uji hipotesis.

\section{HASIL DAN PEMBAHASAN}

Dari hasil olah data yang dilakukan peneliti terlihat fenomena yakni kelompok usia muda dalam rentang 15 sampai dengan 20 tahun memiliki ketertarikan yang lebih tinggi terhadap ebook dibandingkan dengan usia yang lebih tua yaitu 31 sampai dengan 40 tahun. Kelompok usia yang lebih muda diperkirakan mereka yang merupakan generasi $\mathrm{Z}$ masih tercatat sebagai pelajar baik di bangku Sekolah Menengah Atas atau Perguruan Tinggi, dengan demikian masih ada tuntutan untuk gemar membaca pengetahuan dan mereka membacanya melalui buku digital yang sesuai dengan budaya kekinian dan sesuai dengan usianya. Pada kelompok usia yang lebih tua yaitu di atas 41 tahun memiliki angka rata-rata yang cukup tinggi dalam hal sikap kepada ebook yakni 3,03. Diketahui usia ini adalah usia paruh baya atau masuk dalam generasi X di mana dalam usia ini minat membacanya masih tinggi dan untuk mewujdukan keinginan membaca tersebut guna menambah wawasan disalurkannya kepada teknologi kekinian yaitu ebook, di mana mereka juga menikmati setiap kemajuan teknologi yang ada saat ini. Berdasarkan paparan angka rata-rata tersebut dapat dikatakan industri buku digital memiliki potensi yang besar untuk semakin berkembang di Indonesia, karena baik sebaran usia di bawah 30 tahun maupun di atas 40 tahun sama-sama memiliki ketertarikan pada buku digital atau ebook.

Table I Sebaran Kelompok Usia terhadap Sikap pada Ebook, Sikap pada Buku Fisik dan Sikap pada Minat Baca

\begin{tabular}{lllll}
\hline Kelompok Usia & $\begin{array}{l}\text { Angka Rata-rata } \\
\text { pada Ebook }\end{array}$ & $\begin{array}{l}\text { Sikap } \\
\text { pada Buku Fisik }\end{array}$ & $\begin{array}{l}\text { Angka Rata-rata Sikap } \\
\text { pada Minat Baca }\end{array}$ \\
\hline $15-20$ tahun & 2,92 & 2,5 & 2,7 \\
\hline $21-25$ tahun & 2,3 & 2,6 & 2,7 \\
\hline $26-30$ tahun & 3,25 & 2,2 & 2,5 \\
\hline $31-40$ tahun & 2,8 & 2,2 & 2,4 \\
\hline$>41$ tahun & 3,03 & 2,4 & 2,5 \\
\hline
\end{tabular}

Dalam hal sikap terhdaap buku fisik seluruh kelompok usia mulai dari 15 tahun sampai dengan lebih dari 41 tahun memiliki angka rata-rata yang hampir sama. Berbeda dengan sikap pada ebook di mana pada kelompok-kelompok usia tertentu ada yang memiliki nilai rata-rata cukup tinggi. Hal ini menunjukkan fenomena menurunnya minat seseorang untuk membaca buku fisik di tengah gempuran teknologi yang juga mengubah buku fisik menjadi ebook. Terkait dengan minat baca, rentang usia 15 sampai dengan 25 tahun 
memiliki angka rata-rata tertinggi. Hal ini menunjukkan usia tersebut memiliki kebutuhan membaca yang lebih baik dibandingkan usia lainnya. Dari paparan ini terlihat bahwa usia di bawah 25 tahun memiliki ketertarikan atau minat baca yang baik dibandingkan dengan usia di atasnya, namun sama dengan usia di atas 41 tahun yang sudah mulai kembali untuk gemar membaca. Di generasi X minat membaca terasa dibutuhkan kembali seiring dengan aktivitas keseharian yang sudah mulai menurun atau dapat dikatakan jelang masa pensiun. Jika dipaparkan lebih dalam lagi dilihat dari sisi pendidikan sebaran responden sejumlah 126 orang dapat dilihat pada tabel berikut:

Table II Sebaran Kelompok Pendidikan terhadap Sikap pada Ebook, Sikap pada Buku Fisik dan Sikap pada Minat Baca

\begin{tabular}{llll}
\hline Pendidikan & $\begin{array}{l}\text { Angka Rata-rata Sikap } \\
\text { pada Ebook }\end{array}$ & $\begin{array}{l}\text { Angka Rata-rata Sikap } \\
\text { pada Buku Fisik }\end{array}$ & $\begin{array}{l}\text { Angka Rata-rata Sikap } \\
\text { pada Minat Baca }\end{array}$ \\
\hline SD & 2,1 & 2,8 & 2,8 \\
\hline SMP & 3,1 & 2,8 & 2,8 \\
\hline SMA & 2,9 & 2,6 & 2,7 \\
\hline S1 & 2,8 & 2,3 & 2,4 \\
\hline S2 & 2,3 & 1,7 & 2,3 \\
\hline
\end{tabular}

Dari data tersebut dapat dijelaskan responden yang memiliki tingkat pendidikan Sekolah Menengah Pertama (SMP) memiliki ketertarikan yang lebih tinggi pada ebook dibandingkan dengan responden dengan latar pendidikan berbeda. Fenomena yang terjadi di usia ini dapat dikatakan sebagai generasi milenial yang pada kenyataannya memang lebih menyukai hal-hal yang berbasis digital, termasuk dalam hal membaca. Sedangkan angka rata-rata sikap responden terhadap buku fisik mengalami tren menurun dari mulai tingkat pendidikan Sekolah Dasar (SD) sampai dengan S2. Tingkat pendidikan Strata 2 ini memiliki angka rata-rata terkecil dari keseluruhan tingkat pendidikan responden. Kebutuhan untuk membaca dari responden berlatar belakang pendidikan S2 lebih banyak disalurkan ke ebook karena ketertarikan yang lebih pada buku versi tersebut. Berbeda halnya dengan rata-rata sikap responden kepada buku fisik di tingkat pendidikan SD, di mana pada tingkat pendidikan tersebut masih terdapat kewajiban untuk membaca dan memiliki buku fisik sebagai buku wajib di sekolah, sehingga angka rata-ratanya menjadi lebih tinggi.Angka rata-rata minat baca dari responden juga mengalami tren yang menurun dari tingkat pendidikan SD hingga S2. Hal ini menunjukkan keinginan membaca yang sudah mulai berkurang untuk tingkat pendidikan yang semakin tinggi. Kebutuhan membaca untuk ilmu pengetahuan pada tingkat pendidikan yang lebih tinggi seperti S2 mungkin sudah tidak kepada buku lagi tetapi lebih kepada jurnal atau artikel-artikel popular lainnya. Maka terlihat pada data di penelitian ini angka rata-rata sikap responden pada minat baca hanya 2,3.

Secara umum ketertarikan masyarakat yang menjadi responden dalam penelitian ini pada ebook, buku fisik maupun pada minat membaca dapat menjadi perhatian bagi para pelaku bisnis di bidang penerbitan dan percetakan. Bidang bisnis ini dapat difokuskan pada pencetakan bahan bacaan fisik dalam hal ini adalah buku yakni buku ajar dalam tingkat pendidikan tertentu. Buku ajar yang memungkinkan untuk dicetak dalam jumlah banyak sekiranya hanya untuk tingkat pendidikan SD hingga SMA saja, sedangkan untuk tingkat pendidikan yang lebih tinggi seperti S1 atau S2 dapat diterbitkan dalam bentuk digital atau ebook. Fenomena beralihnya teknologi dari yang konvensional menjadi leih modern seperti peminatan buku fisik yang beralih kepada ebook ini tidak dapat dihindari. Hal ini terjadi sebagai akibat dari kemajuan teknologi serta era yang terus berkembang. Pola hidup masyarakat pun berubah, dari yang sebelumnya gemar membaca buku fisik kini beralih menjadi gemar membaca ebook dengan segala kelebihannya seperti lebih praktis atau simpel. Di mana saat ini masyarakat menginginkan proses pemenuhan kebutuhan dan keinginan hidup dengan cara yang lebih mudah dan tidak merepotkan. Kemudahan-kemudahan ini hadir dibawa oleh ebook yang sejak kemunculannya telah memiliki keunggulannya sendiri dan mempengaruhi peminat buku fisik untuk beralih kepada buku digital.

\section{KESIMPULAN}

Sesuai dengan tujuan dilakukannya penelitian ini yaitu untuk mengetahui adanya pengaruh antar variabel maka disimpulkan:

1. Terdapat pengaruh antara sikap terhadap ebook terhadap minat baca

2. Terdapat pengaruh antara sikap terhadap buku fisik terhadap minat baca

3. Terdapat pengaruh antara sikap terhadap ebook dan sikap terhadap buku fisik terhadap minat baca 


\section{Implikasi Manajerial}

Terkait simpulan yang telah dijabarkan pada sub bab di atas, peneliti melihat terhadap beberapa hal yang perlu dilakukan oleh industri penerbitan dan percetakan yaitu:

- Implikasi manajerial pada penelitian ini fokus kepada industri penerbitan dan percetakan untuk menyesuaikan aktifitas usahanya dengan kondisi yang terjadi saat ini, yaitu pencetakan buku fisik yang perlu diperhitungkan lagi jumlahnya dikarenakan pola hidup masyarakat yang sudah bergeser ke arah digitalisasi.

- Hipotesa penelitian yang terbukti yaitu ada pengaruh sikap pada ebook terhadap minat membaca, sikap pada buku fisik terhadap minat membaca dan sikap pada ebook dan buku fisik terhadap minat membaca menjadi masukan bagi pelaku bisnis percetakan dan penerbitan bahwa industri masih dapat tetap bertahan namun harus tetap dengan perhitungan yang matang dalam proses produksinya.

\section{SARAN}

Penelitian ini hanya berfokus pada masyarakat Jabodetabek saja, maka peneliti menyarankan perlunya dilakukan penelitian lebih lanjut terhadap masyarakat yang berdomisili di wilayah berbeda dengan menggunakan variabel yang sama pada penelitian ini, agar dapat menyajikan data yang lebih variatif sehingga keakuratan dapat lebih teruji. Penelitian lebih lanjut tersebut dapat dilakukan dalam bentuk penyebaran kuesioner online namun terdapat metode pendampingan pengisian kuesioner melalui aplikasi pesan pendek, hal ini dimaksudkan agar jangkauan respondennya lebih luas namun keakuratannya tetap teruji.

\section{DAFTAR PUSTAKA}

[1]. Abdi, H., \& Williams, L. J. (2010). Principal Component Analysis. Wiley interdisciplinary reviews: computational statistics, 2(4), 433-459.

[2]. Abdul, R.S., \& Muhib, A.W. (2004). Psikologi Suatu pengantar dalam Perspektif Islam,Prenada Media, Jakarta

[3]. Agatha Claudia Pascal, 2017, Strategi Penerbit Bertahan di Era Ebook, https://industri.kontan.co.id/news/strategi-penerbit-bertahan-di-era-e-book?

[4]. Agustinus Mario Damar, 2019, iJakarta, Tak Sekadar Aplikasi Perpustakaan Digital, https://www.liputan6.com/tekno/read/2510624/ijakarta-tak-sekadar-aplikasi-perpustakaan-digital

[5]. Ajzen, I. (2002). "Perceived behavioral control, self-efficacy, locus of control, and the theory of planned behavior". Journal of Applied Social Psychology, Vol. 32, p. 665-683.

[6]. Annisa Sulistyo Rini, 2018, Industri Percetakan Diproyeksi Tumbuh 5\% Pada Tahun Ini, http://industri.bisnis.com/read/20180702/257/811886/industri-percetakan-diproyeksi-tumbuh-5-padatahun-ini

[7]. Anugra, Yusup \& Erwina. (2013). Faktor-faktor Dominan yang Mempengaruhi Minat Baca Mahasiswa. Jurnal Kajian Informasi dan Perpustakaan. Program Pascasarjana Ilmu Komunikasi Universitas Padjajaran Bandung

[8]. Christine Novita Nababan, 2018, Gerai Toko Buku Aksara Tutup, https://www.cnnindonesia.com/ekonomi/20180416081649-92-291015/gerai-toko-buku-aksara-tutup

[9]. Coviello, N., Milley, R. and Marcolin, B. (2001). Understanding IT-enabled interactivity in contemporary marketing. Journal of Interactive Marketing, 15(4), 18-33

[10].Ema Aprilisa, 2017, Suka Membaca? Manfaatkan 3 Aplikasi Perpustakaan Digital Gratis Ini,

[11].https://www.teen.co.id/read/2624/suka-membaca-manfaatkan-3-aplikasi-perpustakaan-digital-gratis-ini

[12].Fiki Ariyanti, 2017, Mau Jadi Penulis? Ini Pajak yang Harus Dibayar ke Negara, https://www.liputan6.com/bisnis/read/3091730/mau-jadi-penulis-ini-pajak-yang-harus-dibayar-kenegara

[13].Killis, J. (1988). Hubungan Minat Kerja, Motivasi Ekstrinsik dan Bimbingan dalam Pelajaran dengan Kecakapan Kerja Teknik Listrik Lulusan STM pada Industri-industri DIY. Tesis. Fakultas Pasca Sarjana IKIP Jakarta

[14].Luki, 2009, Ebook Berdampak Besar bagi Industri Percetakan, https://www.antaranews.com/berita/145569/e-book-berdampak-besar-bagi-industri-percetakan 
[15].Marie, Jenney. (2017). Electronic Books or Print Books for Icreased Reading Comprehension and Vocabulary Acquisition in Third Grade Students. Thesis. The Faculty of Humboldt State University in Partial Fulfillment of the Requirements for the Degree Masters of Arts in Education

[16].Safyra Primadhita, 2017, Janji Sri Mulyani ke Dewi Lestari Soal Pajak Penulis, https://www.cnnindonesia.com/ekonomi/20170914083114-78-241629/janji-sri-mulyani-ke-dewi-lestarisoal-pajak-penulis

[17].Sanjaya, R. \& Josua, T. (2009). Creative Digital Marketing, PT Elex Media Komputindo, Jakarta

[18].Siti Fatimah, 2017, Industri Precetakan dan Penerbitan Tetap Tumbuh di Era Digital, Pengurus Kadin Pun Gelar Ini,http://jabar.tribunnews.com/2017/11/24/industri-percetakan-dan-penerbitan-tetap-tumbuhdi-era-digital-pengurus-kadin-pun-gelar-ini

[19].Sugiyono. (2012). Metode Penelitian Kuantitatif, Kualitatif, dan R\&D, Alfabeta, Bandung

[20].Suryabrata, S. (1998). Psikologi Pendidikan. Jakarta: PT Raja Grafindo Persada

[21].Trafimow, D. ( 2015). "The Theory of Reasoned Action-A Case study of falsification in psychology". Journal of Theory and Psychology Vol. 19(4), p.501-518.

[22].Witanto, J. (2018). Minat Baca yang Sangat Rendah. Publikasi. Fakultas Keguruan dan Ilmu Pendidikan Universitas Kristen Satya Wacana Salatiga

[23].Yuli Yanna Fauzie, 2018, Penjualan Buku Tergerus, Toko Buku Milik Lippo Genjot e-Book, https://www.cnnindonesia.com/ekonomi/20180417174106-92-291485/penjualan-buku-tergerus-tokobuku-milik-lippo-genjot-e-book

[24].Zang \& Kudva. (2014). E-books Versus Print Books: Readers' Choices and Preferences Across Contexts. Journal of the American Society for Information Science and Technology 